УДК $616.37-002+611-018.1+611-018.54$

Ю. А. Гайдар, Н. Ю. Ошмянская, А. П. Галенко

\title{
Особенности гистоструктуры поджелудочной железы при аутоиммунном панкреатите I и II типов: связь с уровнем IgG4-положительных плазматических клеток
}

ГУ «Институт гастроэнтерологии НАМН Украины», г. Днепропетровск

Ключевые слова: панкреатит, IgG4, гистологические методы.

Дифференциальная диагностика аутоиммунного панкреатита связана с различной степенью вовлеченности в патогенез иммуноглобулина G 4 субкласса. С целью изучения двух форм аутоиммунного панкреатита и их связи с уровнем IgG4-позитивных плазматических клеток в поджелудочной железе с помощью гистологических и иммуногистохимических методов обследовали 54 больных с хроническим панкреатитом, из них отобрано 15 случаев с аутоиммунным панкреатитом. При аутоиммунном панкреатите I типа наблюдали плотный лимфоплазмоцитарный перидуктальный инфильтрат, многоярусный фиброз, облитерирующий

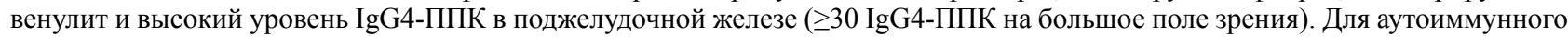
панкреатита II типа, кроме типичных патогистологических признаков аутоиммунного панкреатита, свойственно лейкоцитарное повреждение эпителия панкреатических протоков, низкий уровень IgG4-ППК в поджелудочной железе и очаговые поражения на I-III стадиях заболевания ( $80 \%$ случаев).

Особливості гістоструктури підшлункової залози при аутоімунному панкреатиті I і II типів: зв'язок із рівнем IgG4-позитивних плазматичних клітин

Ю. А. Гайдар, Н. Ю. Оимянська, О. П. Галенко

Диференційна діагностика аутоімунного панкреатиту пов'язана з різним ступенем залученості в патогенез імуноглобуліну G 4 субкласу. 3 метою вивчення двох форм аутоімунного панкреатиту та їх зв'язку з рівнем IgG4-позитивних плазматичних клітин у підшлунковій залозі за допомогою гістологічних та імуногістохімічних методів обстежили 54 хворих на хронічний панкреатит, із них відібрано 15 випадків 3 аутоімунним панкреатитом. При аутоімунному панкреатиті I типу спостерігали щільний лімфоплазмоцитарний перідуктальний інфільтрат, багатоярусний фіброз, облітеруючий венуліт і високий рівень IgG4-ППК у підшлунковій залозі ( $\geq 30$ IgG4-ППК на велике поле зору). Для аутоімунного панкреатиту II типу, крім типових патогістологічних ознак аутоімунного панкреатиту, властиві лейкоцитарне ушкодження епітелію панкреатичних проток, низький рівень IgG4-ППК у підшлунковій залозі й осередкові ураження на I-III стадіях захворювання (80\% випадків).

Ключові слова: панкреатит, IgG4, гістологічні методи.

Патологія. - 2014. - №1 (30). - С. 68-71

Histostructure of pancreas in patients with autoimmune pancreatitis type I and II: connection with the level of IgG4-positive plasma cells

Y. A. Gaidar, N. Y. Oshmyanska, A. P. Halenko

Differential diagnosis of autoimmune pancreatitis apart from everything else is based on specifics of immunoglobulin G4 involvement into the pathogenesis.

Aims: to analyze two forms of autoimmune pancreatitis and their relation to the level of IgG4-positive plasma cells.

Methods and results. The present study was conducted on 54 patients with chronic pancreatitis, from which 15 cases with autoimmune pancreatitis were selected by using morphological and immunohistochemical methods.

Conclusion. It has been established that for autoimmune pancreatitis type I dense lymphocytic periductal infiltrate, multilevel fibrosis, obliterating venulitis and high IgG4-positive plasma cells in the pancreas ( $\geq 30$ per high power field) were typical. In the cases of autoimmune pancreatitis type II, besides the specific histopathological signs of AIP, significantly epithelial damage of pancreatic ducts by leukocytes, low levels of IgG4-PPC in the pancreas and focal lesions on stages I-III of disease (80\%) were observed.

Key words: pancreatitis, IgG4, histological techniques.

Pathologia. 2014; №1 (30): 68-71

Концепция аутоиммунного панкреатита (АИП) предложена Yoshida et al. [1] в 1995 г. В настоящее время различают два подтипа аутоиммунного панкреатита: тип I и тип II, которые имеют характерные четко очерченные патоморфологические признаки. Тип I (лимфоплазмоцитарный склерозирующий панкреатит) чаще диагностируют в США, Великобритании, Японии и Корее. АИП этого типа отличает плотный перидуктальный инфильтрат, состоящий из лимфоцитов и плазматических клеток, в частности IgG4-положительных плазматических клеток (IgG4-ППК) ( $\geq 30$ клеток на боль- шое поле зрения), а также многоярусный фиброз вокруг главного панкреатического и междольковых протоков и перипанкреатической жировой ткани. Дольки поджелудочной железы (ПЖ) относительно хорошо сохранены, в части долек отмечают очаги некроза, замещающиеся фиброзной тканью. Пучки фиброзной ткани смешаны с клетками воспаления, часто обнаруживают эозинофильные и тучные клетки [2,3]. Типичен также облитерирующий флебит, а в ряде случаев можно наблюдать и облитерирующий артериит. Первый тип АИП относят к IgG4-ассоциированным склерозирующим заболеваниям

(C) Ю. А. Гайдар, Н. Ю. Ошмянская, А. П. Галенко, 2014 
[4], он часто сочетается с синдромом Шегрена и/или ретроперитониальным фиброзом [5].

Инфильтрация эпителия главного панкреатического протока и/или междольковых протоков нейтрофильными лейкоцитами - характерная черта АИП II типа (идиопатического протоково-центрического панкреатита) [3]. Считается, что при этом типе АИП уровень сывороточного и тканевого IgG4 не повышается [5,6]. Однако описан случай атипичного АИП I, протекающего с лейкоцитарной инфильтрацией панкреатических протоков [7]. АИП II типа сочетается с хроническими воспалительными заболеваниями кишечника: неспецифическим язвенным колитом и болезнью Крона [3]. Для АИП II типа характерно острое течение.

\section{Цель работы}

Изучение особенностей гистопатологии ПЖ при АИП I и II типа в связи с уровнем IgG4-позитивных плазматических клеток в органе.

\section{Материалы и методы исследования}

Выполнен анализ операционного материала 54 больных с ХП, биоптаты из головки, тела и хвоста ПЖ и печени забирали с диагностической целью во время плановых оперативных вмешательств по поводу осложненных форм ХП в отделении хирургии ГУ «Институт гастроэнтерологии НАМН Украины». Работа выполнена в рамках НИР «Вивчити механізми розвитку фібротичних процесів при хронічному панкреатиті та удосконалити технології їх хірургічної корекції», № госрегистрации $0111 \mathrm{U} 001065$.

Гистологическое исследование. Для гистологических исследований биоптаты фиксировали в 10,0\% растворе нейтрального формалина, обезвоживали в спиртах восходящей концентрации и заливали в парафин. Срезы толщиной 3-5 мкм окрашивали гематоксилином и эозином и по Маллорив мод. Слинченко. Стадии АИП определяли по Zamboni G., Lüttges J., Capelli P. et al (2004, табл. 1) [2].

Активность АИП оценивали как низкую и высокую.
При низкой активности редкие внутриэпителиальные гранулоциты отмечают в одном или нескольких панкреатических протоках, внутри долек наблюдают редкие гранулоциты. При высокой активности заметны повреждения одного или нескольких панкреатических протоков межэпителиальными гранулоцитами, в протоках образуются абсцессы, приводящие к их разрушению, обычно обнаруживают гранулоциты внутри долек и между ними.

Иммуногистохимическое исследование. IgGположительные плазматические клетки (IgG-ППК) выявляли с помощью овечьих антител к человеческому IgG меченных ФИТЦ (Abcam, США); подкласс IgG4положительных плазматических клеток (IgG4-ППК) - с помощью непрямой иммунопероксидазной реакции, используя кроличьи моноклональные антитела к IgG4 (Abcam, США). Звездчатые клетки обнаруживали с помощью специфических моноклональных антител (ВТі-567, США), используя эпифлуоресцентную конфокальную микроскопию на микроскопе «Olympus-2500» (Япония).

Это окрашивание дало последовательные результаты, которые можно было легко интерпретировать. После окрашивания производили идентификацию и количественное определение клеток в области их наибольшей концентрации, в 5 последовательных полях зрения при большом увеличении светового микроскопа (объектив $\times 40$, окуляр $\times 10$ ) и с использованием флуоресцентного микроскопа ЛОМО («Микмед», Российская Федерация). Различали такие уровни IgG4-ППК на большое поле зрения (БПЗ): низкий (10-20 клеток), средний (20-30 клеток) и высокий ( $\geq 30 \mathrm{IgG} 4-П П К)$.

\section{Результаты и их обсуждение}

Из обследованных 54 больных с хроническим фиброзно-дегенеративным панкреатитом отобраны 15 случаев с аутоиммунным панкреатитом. АИП I и II типов, его стадию и активность определяли по характерным гистопатологическим изменениям поджелудочной железы, согласно указанным критериям аутоиммунного панкреатита.

Стадии АИП по Zamboni G. et al.

Таблииа 1

\begin{tabular}{|c|c|c|c|c|}
\hline Стадия & Инфильтрация ткани ПЖ & $\begin{array}{c}\text { Вовлечение протоков } \\
\text { и/или сосудов }\end{array}$ & Распространенность & $\begin{array}{c}\text { Характер } \\
\text { фиброзирования }\end{array}$ \\
\hline I & $\begin{array}{c}\text { рассеянные перидуктальные } \\
\text { лимфоплазматические } \\
\text { инфильтраты }\end{array}$ & $\begin{array}{c}\text { легкое сужение } \\
\text { протоков }\end{array}$ & $\begin{array}{c}\text { почти нет вовлечения } \\
\text { междольковых } \\
\text { и внутридольковых пространств }\end{array}$ & $\begin{array}{c}\text { легкий } \\
\text { вокругдольковый } \\
\text { фриброз }\end{array}$ \\
\hline II & $\begin{array}{c}\text { множественные } \\
\text { перидуктальные } \\
\text { лимфоплазматические } \\
\text { инфильтраты }\end{array}$ & $\begin{array}{c}\text { сужение протоков, } \\
\text { редкий венулит }\end{array}$ & $\begin{array}{c}\text { незначительное вовлечение } \\
\text { междольковых и внутридольковых } \\
\text { пространств }\end{array}$ & $\begin{array}{l}\text { очаговый } \\
\text { многоярусный } \\
\text { фиброз }\end{array}$ \\
\hline III & $\begin{array}{c}\text { диффузная } \\
\text { перидуктальная } \\
\text { лимфоплазматическая } \\
\text { инфильтрация, } \\
\text { лимфатические фролликулы }\end{array}$ & $\begin{array}{c}\text { обструкция/ } \\
\text { разрушение протоков, } \\
\text { облитерирующий флебит }\end{array}$ & $\begin{array}{c}\text { умеренное вовлечение } \\
\text { междольковых и внутридольковых } \\
\text { пространств }\end{array}$ & $\begin{array}{c}\text { вокругдольковый } \\
\text { многоярусный } \\
\text { фиброз }\end{array}$ \\
\hline IV & $\begin{array}{c}\text { диффузная } \\
\text { перидуктальная } \\
\text { лимфоплазматическая } \\
\text { инфильтрация, } \\
\text { лимфатические фролликулы } \\
\text { со светлым центром }\end{array}$ & $\begin{array}{l}\text { часто - венулит, } \\
\text { редко - артериит }\end{array}$ & $\begin{array}{c}\text { выраженное вовлечение } \\
\text { междольковых и внутридольковых } \\
\text { пространств }\end{array}$ & $\begin{array}{c}\text { выраженный } \\
\text { перидуктальный } \\
\text { многоярусный } \\
\text { фиброз и склероз }\end{array}$ \\
\hline
\end{tabular}


В ходе исследования у каждого пациента была проанализирована гистоструктура трех топографических зон ПЖ: головки, тела и хвоста.

АИП І типа диагностирован у пяти больных мужчин, средний возраст - 45,0 лет; давность заболевания - от 1 до 4 лет. В гистологических препаратах ПЖ больных во всех гистотопографических зонах ПЖ отмечены III-IV стадии АИП с характерным плотным перидуктальным лимфоплазматическим инфильтратом (рис. 1, цв. вкладка 5), многоярусным фиброзом, клеточную основу которого составляли звездчатые клетки (рис. 2, цъ. вкладка 5), и облитерирующим флебитом (рис. 3, ц̧в. вкладка 5). В печени наблюдали легкий гепатит (puc. 4, ия. вкладка 5) с небольшим количеством IgG4-ППК (до 5 в БПЗ) в расширенных портальных трактах.

В паренхиме ПЖ всех больных с АИП І типа в плотном лимфоплазмоцитарном инфильтрате вокруг магистральных и междольковых панкреатических протоков и лимфатических фолликулов отмечали компактные скопления IgG-ППК (рис. 5), среди которых диффузно

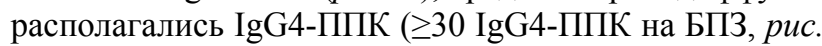
6, цв. вкладка 5).

У обследованных больных диагностировали диффузное поражение поджелудочной железы на III (3 случая) и $\mathrm{IV}(2$ случая) стадиях АИП. Во всех случаях наблюдали осложненные формы течения АИП: у 60\% (3 человека) - хронический фиброзно-кистозный панкреатит, у 40\% (2 человека) - хронический фиброзно-калькулезный панкреатит.

Известно, что обнаружение трех характерных гистологических признаков в пораженной ПЖ позволяет отнести АИП I типа к IgG4-ассоциированным склерозирующим заболеваниям: плотный лимфоплазматический инфильтрат вокруг магистральных протоков ПЖ, многоярусный фиброз, облитерирующий флебит [6,7]. Эти признаки обнаружены во всех рассмотренных нами случаях. Важный факт - обнаружение у всех больных высокого уровня IgG4-ППК вокруг магистральных протоков ПЖ.

Гистотопографическое изучение АИП І типа позволило отметить диффузное поражение ПЖ. Как известно, чаще при АИП I типа в патологический процесс вовлекается вся железа. Однако возможны и очаговые формы АИП І типа с изолированным поражением преимущественно головки и/или хвоста [2]. Диффузное поражение поджелудочной железы в наших случаях объясняем осложненным течением заболевания (кисты, калькулез). Полученные данные подтверждают, что, наряду с характерной гистопатологией, высокий уровень тканевых IgG4-ППК ( $\geq 30$ IgG4-ППК на БПЗ) служит объективным диагностическим критерием АИП І типа.

АИГ II типа установлен у 10 больных (1 женщина и 9 мужчин), средний возраст - 42,5 лет. При гистологическом исследовании ПЖ у 2 пациентов этой группы отмечена диффузная, а у 8 - очаговая форма АИП. У одного больного с диффузной формой АИП диагностирована IV стадия, у второго - II стадия АИП. Активность АИП у этих больных была минимальной.

Очаговая форма АИП II типа с изолированным поражением тела ПЖ зарегистрирована у 3 больных (с II-III стадиями АИП), у 2 отмечено поражение хвоста (I и II стадии АИП), у 1 больной панкреатит ограничивался головкой ПЖ (І стадия АИП); еще у 2 больных обнаружено одновременное поражение тела и хвоста ПЖ (II стадия АИП) с интактной головкой.

Как при диффузной, так и при очаговой форме АИП II типа в эпителии магистральных, собирательных и ацинарных протоков ПЖ регулярно определяли одиночные и множественные нейтрофильные лейкоциты, иногда образующие микроабсцессы. В протоках отмечены также участки десквамации эпителия, фигуры митоза эпителиоцитов (рис. 7, 8, ив. вкладка б).

Такая высокая активность АИП II типа отмечена у половины больных. Лимфоплазмоцитарная инфильтрация стромы охватывала не только протоки, но и дольки ПЖ (рис. 9, изв. вкладка б). На III-IV стадиях АИП II типа в фиброзной ткани регулярно отмечали облитерирующий флебит (рис. 10, ив. вкладка б). В перидуктальной фиброзной ткани и вокруг долек обнаруживали скопления IgG-ППК. У всех больных наблюдали фокальные компактные скопления IgG4-ППК в перидуктальной и вокругдольковой фиброзной ткани. Уровень IgG4-ППК составлял 5-10 на БПЗ (рис. 11, ияв. вкладка 6).

У одного больного этой группы с IV стадией АИП диагностирован панкреатогенный диабет, отличающийся наличием в ПЖ мелких и средних по размеру эндокринных островков с гипоплазией $\beta$-клеток (рис. 12, цв. вкладка б).

Таким образом, в наших исследованиях подтверждено существование двух четко очерченных гистологических типов АИП, которые различались как количеством, так и характером расположения IgG4-ППК в ПЖ. При АИП I типа наибольшая концентрация IgG4-ППК отмечена в лимфоплазмоцитарных инфильтратах вокруг магистральных панкреатических протоков, а при АИП II типа обнаруживали только небольшое количество клеток (5-10 на БП3), расположенных в виде небольших фокальных скоплений вокруг протоков и в вокругдольковой фиброзной ткани.

Различная степень вовлечения IgG4 в этиопатогенез обоих типов АИП может свидетельствовать о различной молекулярной природе аутоантигенов, вызывающих иммуновоспалительный процесс в поджелудочной железе. Например, карбоангидраза II типа, расположенная в эпителии панкреатических протоков, может быть мишенью аутоиммунных процессов при АИП ІІ типа.

\section{Выводы}

1. При аутоиммунном панкреатите I типа обнаруживают плотный лимфоплазматический перидуктальный инфильтрат, многоярусный фиброз, облитерирующий венулит и высокий уровень IgG4-ППК в ПЖ ( $\geq 30$ IgG4ППК на БПЗ).

2. Для аутоиммунного панкреатита II типа, кроме характерных патогистологических признаков АИП, типично лейкоцитарное повреждение эпителия панкреатических протоков и низкий уровень IgG4-ППК в ПЖ.

3. При АИП ІІ типа в $80 \%$ случаев отмечают очаговые поражения ПЖ на I-III стадиях заболевания.

Перспективным направлением дальнейших исследований считаем разработку простой и доступной методики диагностики АИП I и II типов. 


\section{Список литературы}

1. Chronic pancreatitis caused by an autoimmune abnormality. Proposal of the concept of autoimmune pancreatitis / [K. Yoshida, F. Toki, T. Takeuchi et al.]. - Dig. Dis. Sci. 1995 - P. 1561-8.

2. Histopathological features of diagnostic and clinical relevance in autoimmune pancreatitis: a study on 53 resection specimens and 9 biopsy specimens / [G. Zamboni, J. Lüttges, P. Capelli et al.]. - Wirchows Arch., 2004. - P. 552-563.

3. Idiopathic chronic pancreatitis with periductal lymphoplasmacytic infiltration. Clinicopathologic features of 35 cases / [K. Notohara, L.J. Burgart, D. Yadav et al.] // American Journal of Surg. Pathol. - 2003. - Vol. 27. - P. 1119-1127.

4. IgG4-related disease: Historical overview and pathology of hematological disorders / [Y. Sato, K. Notohara, M. Kojima et al.] // Pathology International. - 2010. - Vol. 60. - P. 247-258.

5. International consensus diagnostic criteria for autoimmune pancreatitis: guidelines of the International Association of Pancreatology / [T. Shimosegawa, S.T. Chari, L. Frulloni et al.] // Pancreas. - 2011. - Vol. 40. - P. 352-358.

6. Deshpande V. The pathology of IgG4-related disease: critical issues and challenges / V. Deshpande // Semin.Diagn. Pathol. - 2012. - Vol. 29. - № 4. - P. 191-196.

7. Autoimmune pancreatitis with histologically proven lymphoplasmacytic sclerosing pancreatitis with granulocytic epithelial lesions / [T. Ikeura, M. Takaoka, K. Uchida et al.] // International. Medicine. - 2012. - Vol. 51. - № 7. - P. 733-737.

\section{References}

1. Yoshida, K., Toki, F., Takeuchi, T., Watanabe, S., Shiratori, K. \& Hayashi, N. (1995). Chronic pancreatitis caused by an autoimmune abnormality. Digestive diseases and sciences, 40(7), 1561-1568.

2. Zamboni, G., Luttges, J., Capelli, P., Frulloni, L., Cavallini, G., Pederzoli, et al. (2004). Histopathological features of diagnostic and clinical relevance in autoimmune pancreatitis: a study on 53 resection specimens and 9 biopsy specimens. VirchowsArchiv, 445(6), 552-563.

3. Notohara, K., Burgart, L., Yadav, D., Chari, S. \& Smyrk, T. (2003). Idiopathic chronic pancreatitis with periductallymphoplasmacytic infiltration: clinicopathologic features of 35 cases. The American journal of surgical pathology, 27(8), 1119-1127.

4. Sato, Y., Notohara, K., Kojima, M., Takata, K., Masaki, Y. \& Yoshino, T. (2010). IgG4-related disease: Historical overview and pathology of hematological disorders. Pathology international, 60(4), 247 -258. doi: 10.1111/j.1440-1827.2010.02524.x.

5. Shimosegawa, T., Chari, S., Frulloni, L., Kamisawa, T., Kawa, S., et al. (2011). International consensus diagnostic criteria for autoimmune pancreatitis: guidelines of the International Association of Pancreatology. Pancreas, 40(3), 352-358. doi: 10.1097/ MPA.0b013e3182142fd2.

6. Deshpande, V. (2012). The pathology of IgG4-related disease: critical issues and challenges. Seminars in diagnostic pathology, 29(4), 191-196. doi: 10.1053/j.semdp.2012.08.001.

7. Ikeura, T., Takaoka, M., Uchida, K., Shimatani, M., Miyoshi, H., et al. (2011). Autoimmune pancreatitis with histologically proven lymphoplasmacyticsclerosing pancreatitis with granulocytic epithelial lesions. Internal medicine, 51(7), 733-737.

\section{Сведения об авторах:}

Гайдар Ю.А., д. мед. н., зав. лабораторией патоморфологии ГУ «Институт гастроэнтерологии НАМН Украины», E-mail: yuriigaidar@mail.ru.

Ошмянская Н.Ю., мл. научный сотрудник лаборатории патоморфологии ГУ «Институт гастроэнтерологии НАМН Украины». Галенко А.П., научный сотрудник лаборатории патоморфологии ГУ «Институт гастроэнтерологии НАМН Украины». 


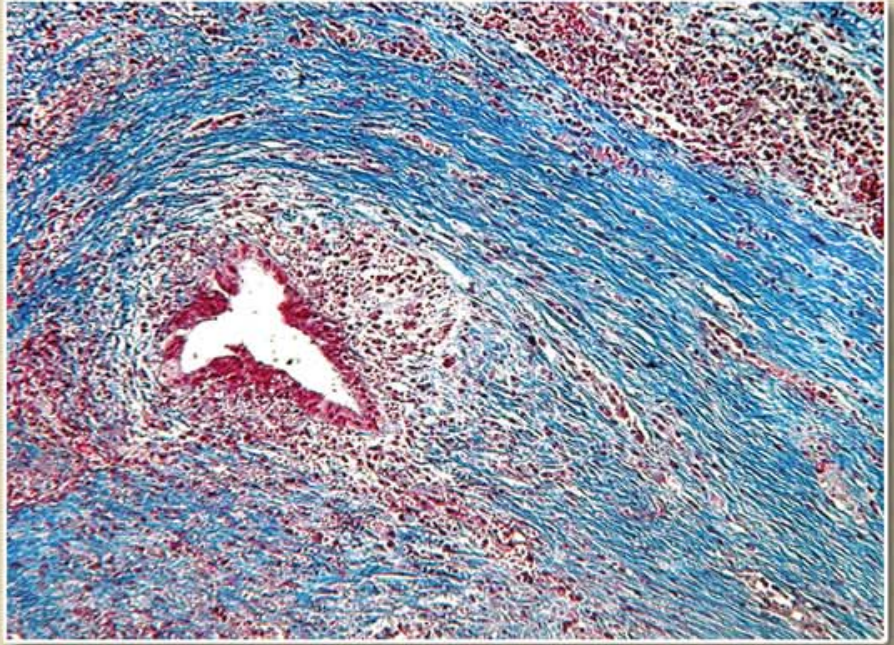

Puc. 1. АИП I типа, IV стадия. Плотный инфильтрат вокруг суженного магистрального протока. Окраска по Маллори в мод. Слинченко. Ув. х100.

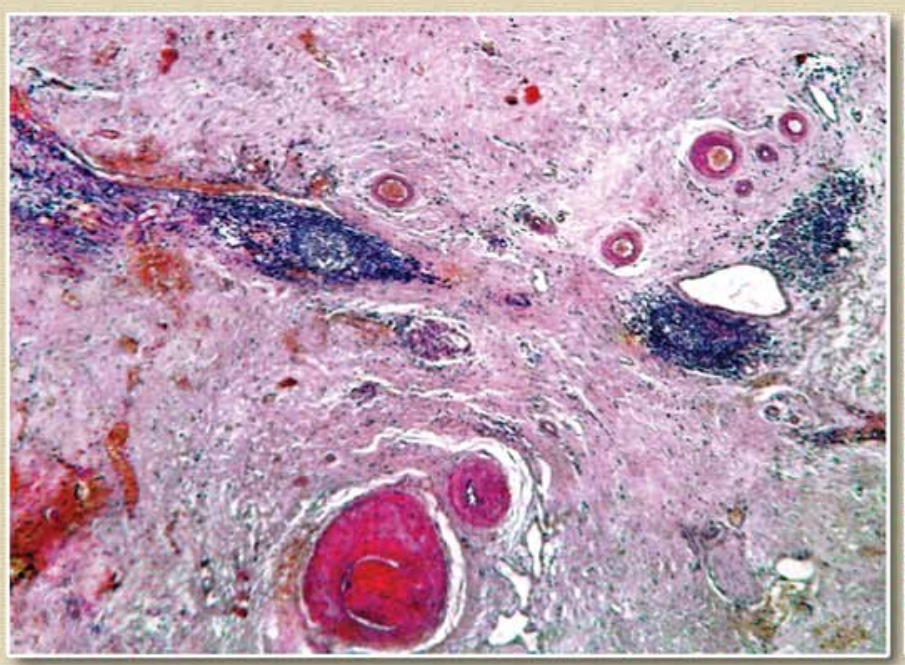

Puc. 3. АИП II типа, облитерация вен.

Окраска гематоксилином и эозином. Ув. х40.

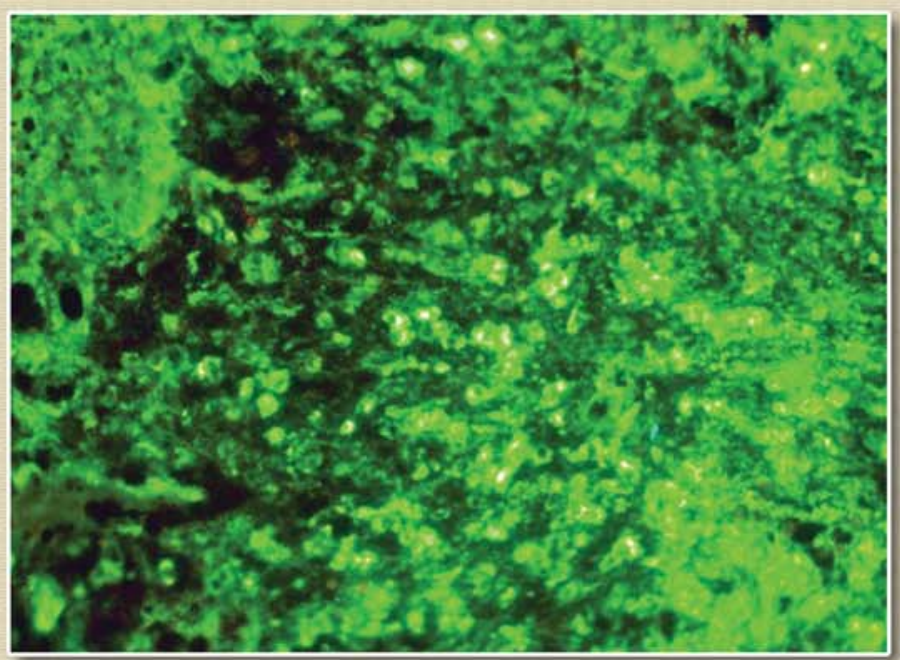

Puc. 5. АИП II типа, облитерирующий флебит Непрямая иммунофлуоресценция. Ув. х100

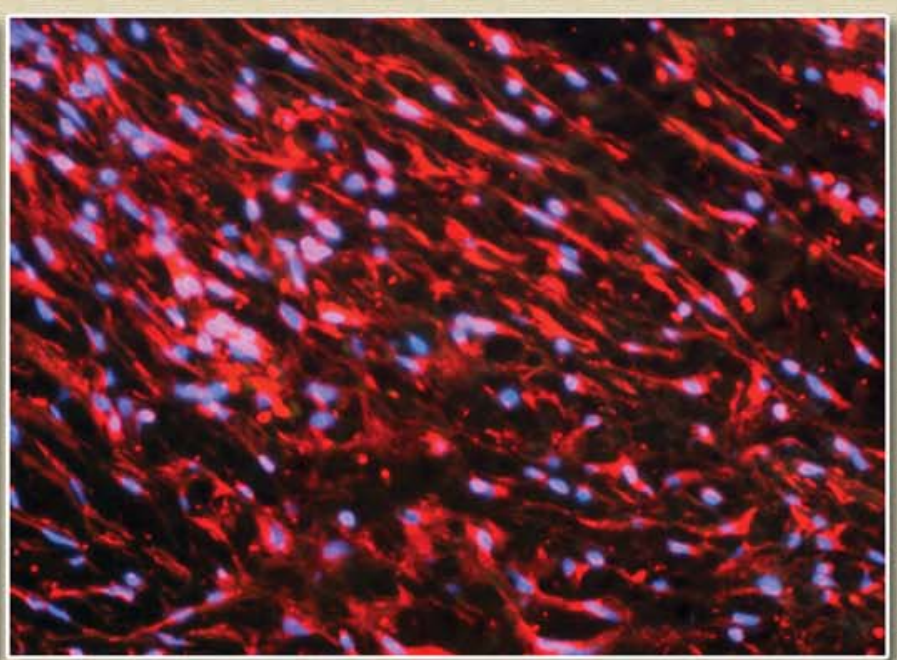

Puc. 2. АИП II типа. Многоярусная фиброзная ткань образована звездчатыми клетками. Конфокальная эпифлуоресцентная микроскопия. Ув. х400.

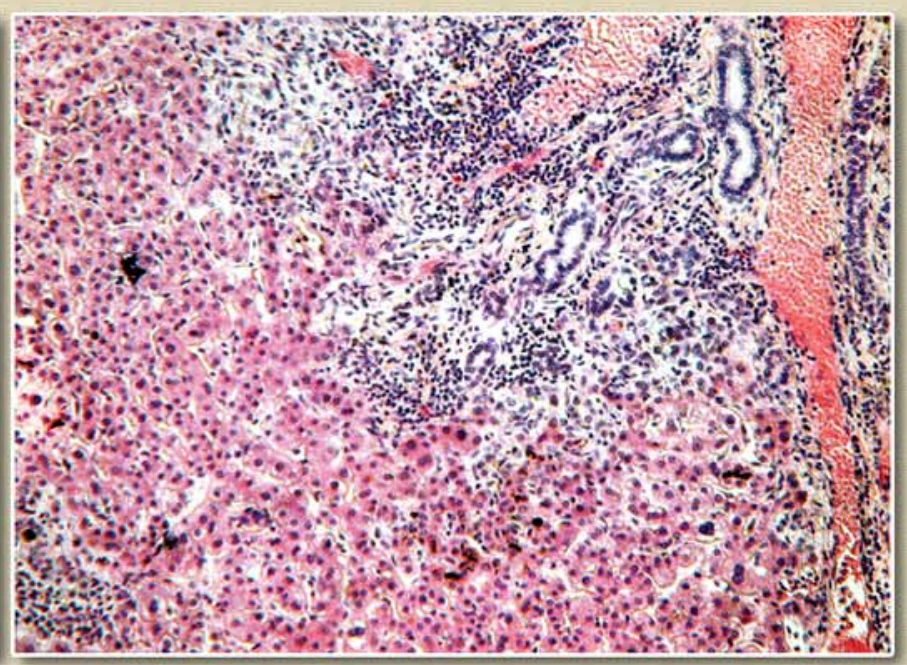

Puc. 4. АИП II типа. В печени - хронический гепатит F1, A0 по шкале Metavir. Окраска гематоксилином и эозином. Ув. х40.

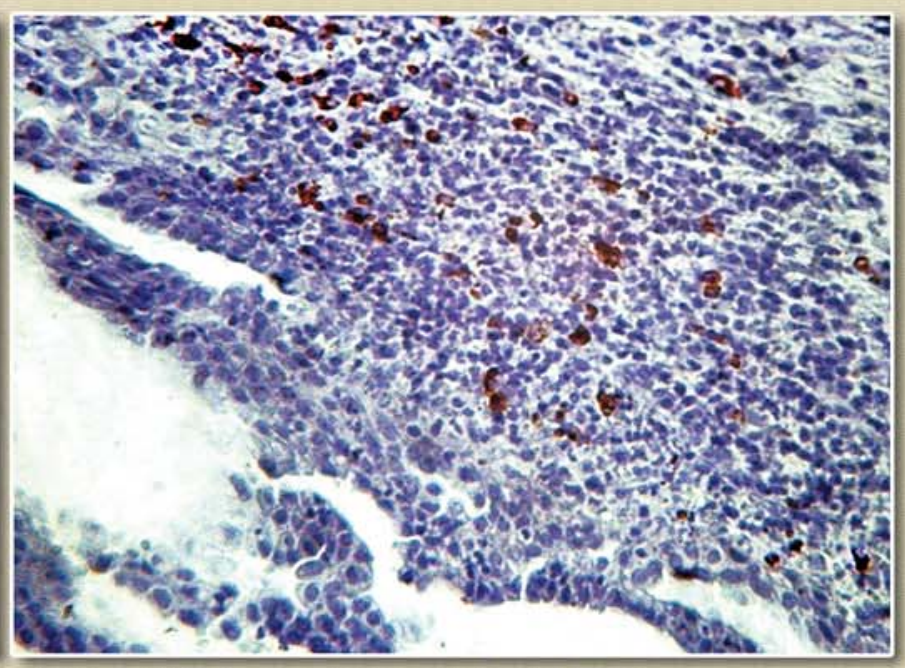

Puc. 6. АИП II типа. Скопления IgG4-ППК

в лимфоплазматическом инфильтрате вокруг магистрального панкреатического протока.

Непрямая иммуногистохимическая реакция. Ув. х200.

(Рuc. 1-6 к статье Ю. А. Гайдара, Н. Ю. Ошмянской, А. П. Галенко «Особенности гистоструктуры поджелудочной железы при аутоиммунном панкреатите I и II тuпа: связь с уровнем IgG4-положительных плазматических клеток», с. 68-71) 


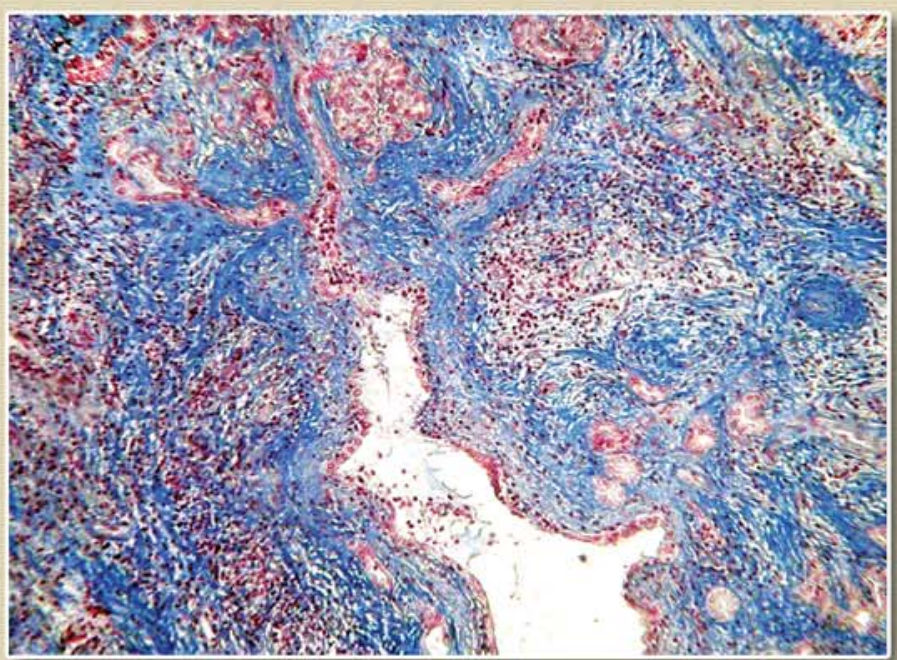

Puc. 7. АИП II типа, стадия III. Сужение магистрального панкреатического протока, фиброз стромы, атрофия ацинарной ткани. Окраска по Маллори в мод. Слинченко. Ув. $\times 100$.

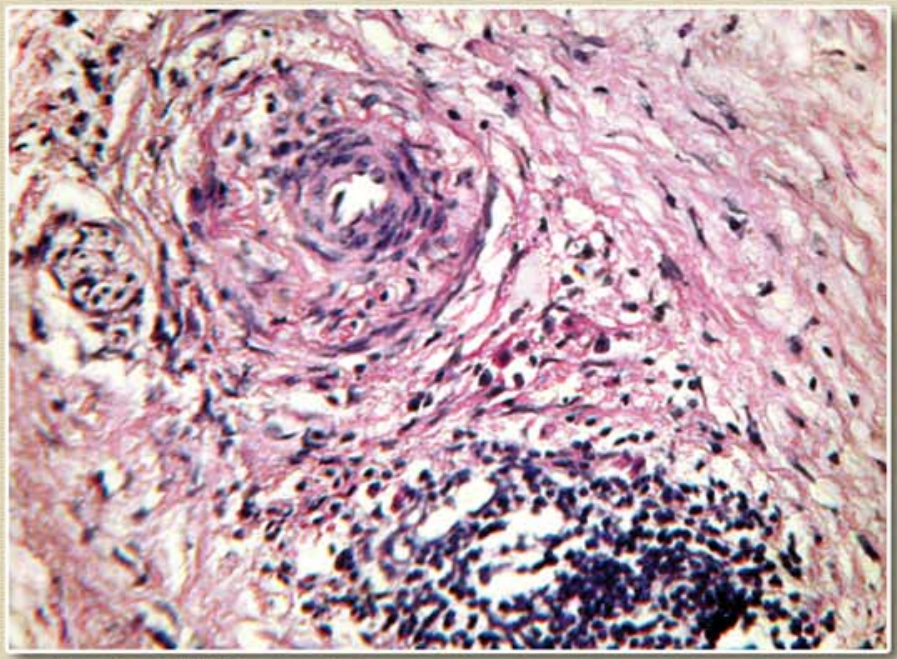

Puc. 9. АИП II типа. Повреждение ацинарной ткани воспалительным инфильтратом.

Окраска гематоксилином и эозином. Ув. х200.

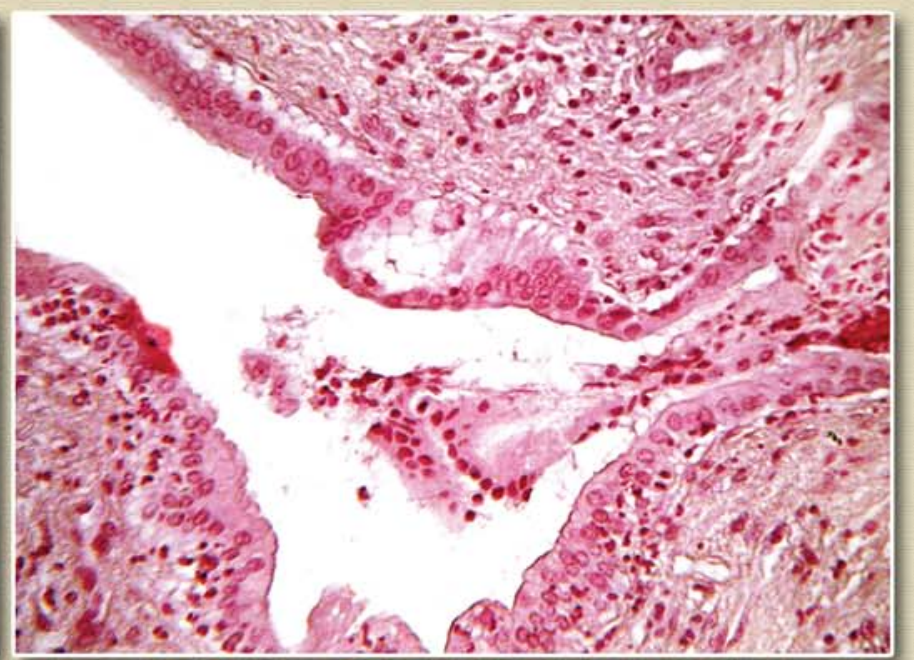

Puc. 8. АИП II типа. Повреждение нейтрофильными лейкоцитами протокового эпителия.

Окраска гематоксилином и эозином. Ув. х200.

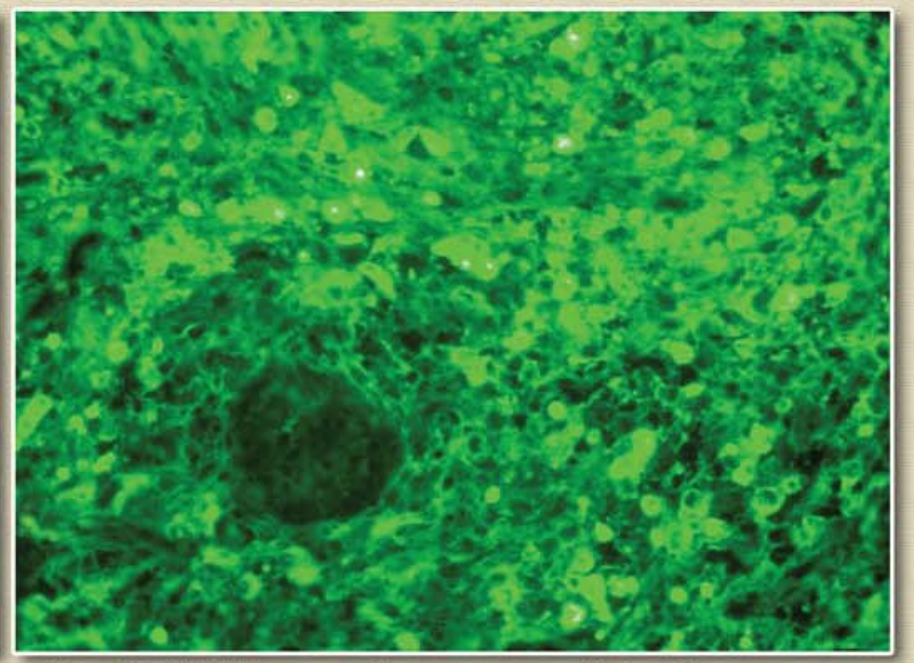

Puc. 10. АИП II типа, облитерирующий флебит.

Реакция непрямой иммунофллуоресценции. Ув. х200.

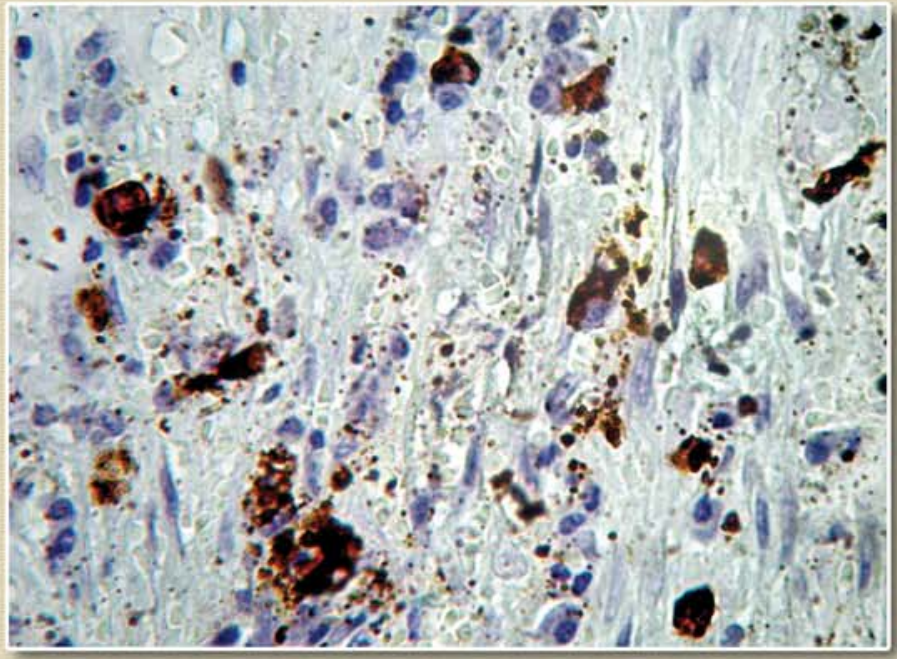

Puc. 11. АИП II типа, стадия III. IgG4-ППК в фиброзной ткани. Непрямая иммунопероксидазная реакция. Ув. х400.

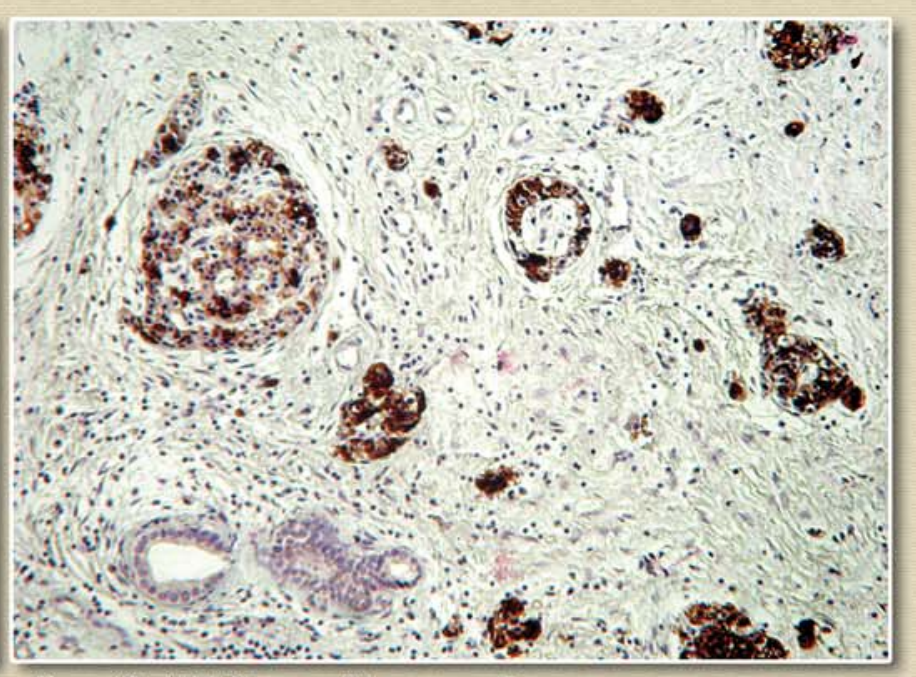

Puc. 12. АИП II типа, IV стадия. Группы мелких островков с малым числом $\beta$-клеток и низким содержанием в них инсулина. Непрямое иммунопероксидазное выявление инсулина. Ув. х100.

(Рис. 7-12 к статье Ю. А. Гайдара, Н. Ю. Ошмянской, А. П. Галенко «Особенности гистоструктуры поджелудочной железы при аутоиммунном панкреатите I и II типа: связь с уровнем IgG4-положительных плазматических клеток», с. 68-71) 